\title{
Replacement of soybean meal by babassu pie in balanced rations for broilers from one to 21 days of age ${ }^{1}$
}

\author{
Substituição do farelo de soja pela torta de babaçu em rações \\ balanceadas para frangos de corte de 1 a 21 dias de idade ${ }^{1}$
}

\author{
Mônica Calixto da Silva²; Jefferson Costa de Siqueira ${ }^{3 *}$; Roberta Gomes Marçal \\ Vieira Vaz ; Kênia Ferreira Rodrigues ${ }^{4}$; Luiz Fernando Teixeira Albino ${ }^{5}$; \\ Luciano Fernandes Sousa ${ }^{4}$; Ana Cláudia Gomes Rodrigues Neiva ${ }^{4}$; \\ Flávia Luzia Rodrigues Fonseca ${ }^{2}$; Joana Patrícia Lira de Sousa ${ }^{6}$; Iberê Pereira \\ Parente ${ }^{4}$; Carla Fonseca Alves Campos $^{7}$; Ariane de Sousa Rodrigues Silva ${ }^{8}$
}

\begin{abstract}
The objective of the present study was to evaluate the effect of substitution level of soybean meal by babassu pie on the performance and cost feed rations to broilers of one to 21 days of age. Two hundred male broiler chicks at one day of age were used, distributed in a completely randomized design with four treatments $(0,10,20$ and $30 \%$ substitution of soybean meal by babassu pie) with five repetitions of 10 broilers each. The performance (weight gain, feed intake, feed conversion and water intake), organ biometrics, feed cost per kg and per kilogram body weight were evaluated. The substitution of soybean meal by babassu pie was significantly in $(\mathrm{P}<0.05)$ negatively weight gain, feed conversion, water intake and body weight at 21 days of age, with no effect $(\mathrm{P}>0.05)$ on feed intake. The levels of substitution of soybean meal by babassu pie did not affect $(\mathrm{P}>0.05)$ the relative weights of the heart or liver, or the relative weight or length of the small intestine; however, it did affect $(\mathrm{P}<0.05)$ the relative weight of the gizzard. The lowest cost per kg was obtained from weight gain satisfaction with the diet of $0 \%$ babassu pie, which resulted in a higher gross margin for food. The replacement of soybean meal by babassu pie impaired the performance of broilers from one to 21 days of age, being technically and economically unfeasible.
\end{abstract}

Key words: Alternative food, co-products of babassu, feed cost

1 Parte da Dissertação de Mestrado da primeira autora.

2 Discentes do Curso de Doutorado do Programa de Pós-Graduação em Ciência Animal Tropical, UFT, Araguaína, TO, Brasil. E-mail: monicalixto_@hotmail.com; flrf@outlook.com

3 Prof. Dr., Universidade Federal do Maranhão, UFMA, Centro de Ciências Agrárias e Ambientais, Chapadinha, MA, Brasil. Bolsista FAPEMA. E-mail: jcsiqueira@ufma.br

4 Profs. Drs., Dept ${ }^{\mathrm{o}}$ de Zootecnia da Escola de Medicina Veterinária e Zootecnia, Universidade Federal do Tocantins, UFT, Araguaína, TO, Brasil. E-mail: betagmvvaz@yahoo.com.br; rodrigueskf@mail.uft.edu.br; luciano.sousa@mail.uft.edu.br; aclaudianeiva@gmail.com; iberepereira@hotmail.com

5 Prof. Dr., Universidade Federal de Viçosa, UFV, Dept ${ }^{\circ}$ de Zootecnia, Viçosa, MG, Brasil. E-mail: lalbino@ufv.com

${ }^{6}$ Prof $f^{a}$ Dra , Instituto Federal de Educação, Ciência e Tecnologia do Tocantins, Dianópolis, TO, Brasil. E-mail: jp-zoot@hotmail. com

7 Discente do Curso de Mestrado do Programa de Pós-graduação em Ciência Animal Tropical, UFT, Araguaína, TO, Brasil. E-mail: carlafazoo@hotmail.com

8 Zootecnista, Autônoma, Araguaína, TO, Brasil. E-mail: arianezoo2012@hotmail.com

* Author for correspondence 


\title{
Resumo
}

\begin{abstract}
Objetivou-se com este trabalho avaliar a viabilidade técnica e econômica da substituição do farelo de soja pela torta de babaçu em rações balanceadas para frangos de corte, de um a 21 dias de idade. Foram utilizados 200 pintos de um dia, distribuídos em delineamento experimental inteiramente casualizado (DIC), com quatro tratamentos $(0,10,20$ e $30 \%$ de substituição do farelo de soja pela torta de babaçu) e cinco repetições de dez aves. Foram avaliados o desempenho produtivo (ganho de peso, consumo de ração, conversão alimentar e ingestão de água), a biometria dos órgãos e o custo da alimentação por kg de frango produzido. A substituição do farelo de soja pela torta de babaçu influenciou $(\mathrm{P}<0,05)$ negativamente o ganho de peso, a conversão alimentar, a ingestão de água e o peso das aves aos 21 dias, não havendo efeito $(\mathrm{P}>0,05)$ sobre o consumo de ração. Os níveis de substituição do farelo de soja pela torta de babaçu não afetaram $(\mathrm{P}>0,05)$ os pesos relativos do coração, fígado, nem o peso relativo ou comprimento do intestino delgado, entretanto, afetou $(\mathrm{P}<0,05)$ o peso relativo da moela. $\mathrm{O}$ menor custo por $\mathrm{kg}$ de ganho de peso foi obtido com a dieta contento $0 \%$ de torta de babaçu, o que resultou na maior margem bruta em relação a alimentação. A substituição do farelo de soja pela torta de babaçu prejudicou o desempenho de frangos de corte de um a 21 dias de idade, sendo técnica e economicamente inviável.

Palavras-chave: Alimento alternativo, coprodutos do babaçu, custo da alimentação
\end{abstract}

\section{Introduction}

Corn and soybean meal, traditionally used in poultry feed, makes production prone to changes in market prices and taxes across different regions of the country (BASTOS et al., 2007; BRUNELLI et al., 2006; HENZ et al., 2013; NASCIMENTO et al., 2005; RAMOS et al., 2006; SCHOULTEN et al., 2003). Therefore, this study was made to identify alternative regional products to be used in the feeding program of broilers to reduce feed costs without compromising production performance.

Studies have been conducted with alternative foods from industrial processing of vegetable origin with the potential to replace corn and soybean meal in the poultry feeding program (BASTOS et al., 2007; NASCIMENTO et al., 2005; RAMOS et al., 2006). Among these is babassu pie from the industrialization processing of the babassu coconut, an alternative nutrient source that can be used in poultry feed. Researches have been conducted based on its use and the results demonstrated several potentialities in broiler nutrition (CARNEIRO et al., 2009; SANTOS NETA et al., 2011).

Santos Neta et al. (2011) evaluated increasing levels of inclusion of babassu pie (0, 4, 8 and $12 \%)$ in broiler rations of one to 21 days and did not find effects in any of the performance characteristics.
In a similar work, Carneiro et al. (2009) used the levels of inclusion of babassu pie (3, 6, 9 and $12 \%)$ and found that inclusion of up to $12 \%$ of food in the diets did not affect feed intake, weight gain or feed conversion, broiler 21-42 days old.

Given the above, the objective was to assess the levels of substitution soybean meal with babassu pie $(0 \%, 10 \%, 20 \%$ and $30 \%)$ in balanced rations for broilers aged $1-21$ days of age.

\section{Materials and Methods}

The experiment was conducted at the Poultry Section of the School of Veterinary Medicine and Animal Science of the Federal University of Tocantins located in Araguaína, TO, from 27 January to 16 February 2012. The work was approved and implemented in accordance with the rules of the Federal University of Tocantins Ethics Committee on Animal Use (CEUA-UFT), process number 23101.001308/2013-62.

Two hundred one-day-old Cobb $500^{\circledR}$ broiler chicks with an average initial weight of $48 \pm$ $2.17 \mathrm{~g}$ were used. The broilers were housed in an experimental shed covered with babassu straw, concrete floor, equipped with cages of $1.0 \times 1.0 \mathrm{x}$ $0.5 \mathrm{~m}$, with feeders and drinkers type rail pressure 
cup. The supply of feeders, cleaning and refueling of drinkers was performed twice a day to ensure free access to water and feed throughout the experimental period.

Broilers were artificially heated using incandescent lamps $(60 \mathrm{~W})$ installed inside the cages until the 14th day of age. Environmental conditions inside the premises during the experimental period were monitored and recorded daily using dry-bulb, wet-bulb and maximum/minimum thermometers placed halfway up the cages allowing the calculation of average, maximum and minimum temperatures and relative humidity.
The broilers were homogenized and the treatments were distributed in a completely randomized design (CRD) with four treatments (0, 10,20 and $30 \%$ replacement of soybean meal with babassu pie) and five replicates of ten broilers per experimental unit.

The experimentalmeals were calculatedassuming the chemical composition of the ingredients (Table 1) and the nutritional requirements of broilers in accordance with the recommendations of Rostagno et al. (2011) (Table 2).

Table 1. Composition of the main ingredients used in the formulation of the experimental diets (based on natural matter).

\begin{tabular}{lccc}
\hline Nutrient & Corn & Soybean Meal & Babassu Pie \\
\hline Gross energy (kcal/kg) & $3983^{1}$ & $4340^{1}$ & $4556^{1}$ \\
Metabolizable energy (kcal/kg) & $3381^{3}$ & $2254^{3}$ & $2268^{2}$ \\
Gross protein (\%) & $9.04^{1}$ & $44.06^{1}$ & $21.26^{1}$ \\
Calcium (\%) & $0.03^{3}$ & $0.24^{3}$ & $0.12^{3}$ \\
Available phosphorous (\%) & $0.06^{3}$ & $0.22^{3}$ & $0.41^{3}$ \\
Digestible lysine (\%) & $0.20^{3}$ & $2.57^{3}$ & $0.38^{3}$ \\
Methionine+cystine (\%) & $0.32^{3}$ & $1.13^{3}$ & $0.31^{3}$ \\
Methionine (\%) & $0.16^{3}$ & $0.55^{3}$ & $0.37^{3}$ \\
Threonine (\%) & $0.29^{3}$ & $1.57^{3}$ & $0.35^{3}$ \\
Sodium (\%) & $0.02^{3}$ & $0.02^{3}$ & $0.06^{3}$ \\
Potassium (\%) & $0.29^{3}$ & $1.83^{3}$ & $0.48^{3}$ \\
Chlorine (\%) & $0.06^{3}$ & $0.05^{3}$ & ----- \\
Gross fiber (\%) & $1.97^{1}$ & $9.67^{1}$ & $29.21^{1}$ \\
Fiber in neutral detergent (\%) & $13.85^{1}$ & $21.73^{1}$ & $58.63^{1}$ \\
Fiber in acid detergent (\%) & $3.16^{1}$ & $6.74^{1}$ & $30.64^{1}$ \\
\hline
\end{tabular}

${ }^{1}$ Analyses carried out at the Animal Nutrition Laboratory of the School of Veterinary Medicine and Animal Science of the Federal University of Tocantins.

${ }^{2}$ Santos Neta (2010).

${ }^{3}$ Rostagno et al. (2011).

The variables evaluated were feed intake (FI), weight gain (WG), feed conversion (FC), final weight (FW), water intake (H2O Intake), organ biometry (heart, liver, gizzard and small intestine) and the cost of feeding per kilogram of chicken produced.

The broilers were weighed at the beginning and end of the experiment for the determination of WG.
The FI was calculated based on the amount of feed and leftovers in the feeders. The FC was calculated through the ratio of feed intake and weight gain of broilers.

A measuring cylinder with a capacity of $1 \mathrm{~L}$ was used. The water intake of each experimental unit was recorded daily at 08:00 and 16:00 to register H2O Intake. The water in the trough was collected 
before being discarded. The waste feed and excreta were separated using a 0.05 mesh sieve. An additional drinking fountain was placed in the shed to estimate water loss by evaporation. Water intake was determined by summing the volumes supplied and discounting evaporation losses at the end of the phase.

Table 2. Composition of the experimental diets containing increasing levels of substitution of soybean meal with babassu pie for broilers between one and 21 days old.

\begin{tabular}{lcccc}
\hline \multirow{2}{*}{ Ingredients } & \multicolumn{3}{c}{ Levels of replacement of soybean meal by babassu pie (\%) } \\
\cline { 2 - 4 } & 0 & 10 & 20 & 30 \\
\hline Corn & 57.090 & 57.090 & 57.090 & 57.090 \\
Soybean meal (45\%) & 35.184 & 31.666 & 28.147 & 24.629 \\
Babassu pie & 0.000 & 3.518 & 7.037 & 10.555 \\
Dicalcium phosphate & 1.601 & 1.603 & 1.605 & 1.607 \\
Soy oil & 1.760 & 2.150 & 2.539 & 2.928 \\
Limestone & 0.893 & 0.915 & 0.937 & 0.959 \\
Common salt & 0.438 & 0.439 & 0.439 & 0.440 \\
DL- Methionine & 0.321 & 0.350 & 0.379 & 0.408 \\
L-Lysine HCl & 0.298 & 0.401 & 0.504 & 0.606 \\
L-Threonine & 0.093 & 0.137 & 0.181 & 0.224 \\
Mineral and vitamin suplement ${ }^{1}$ & 0.500 & 0.500 & 0.500 & 0.500 \\
Washed sand (inert) & 1.800 & 1.211 & 0.625 & 0.036 \\
\hline Total & 100.00 & 100.00 & 100.00 & 100.00 \\
\hline & Calculated nutritional composition & & \\
\hline ME (kcal/kg) & 2950 & 2950 & 2950 & 2950 \\
Gross protein (\%) & 21.50 & 20.75 & 20.01 & 19.26 \\
Calcium (\%) & 0.870 & 0.870 & 0.870 & 0.870 \\
Available phosphorous (\%) & 0.409 & 0.409 & 0.409 & 0.409 \\
Diestible lysine (\%) & 1.242 & 1.242 & 1.242 & 1.242 \\
Methionine + cystine Digestible (\%) & 0.895 & 0.895 & 0.895 & 0.895 \\
Digestible methionine (\%) & 0.614 & 0.634 & 0.655 & 0.675 \\
Digestible threonine (\%) & 0.808 & 0.808 & 0.808 & 0.808 \\
Gross fiber (\%) & 4.527 & 5.214 & 5.902 & 6.589 \\
Fiber in neutral detergent (\%) & 15.552 & 16.851 & 18.149 & 19.447 \\
Fiber in acid detergent (\%) & 4.175 & 5.016 & 5.857 & 6.698 \\
Sodium (\%) & 0.215 & 0.215 & 0.215 & 0.215 \\
Limestone (\%) & 0.313 & 0.312 & 0.310 & 0.309 \\
Potassium (\%) & 0.809 & 0.762 & 0.714 & 0.667 \\
Electrolytic balance (mEq/kg) ${ }^{2}$ & 212.3 & 200.4 & 188.8 & 177.0 \\
\hline
\end{tabular}

${ }^{1}$ Composition/ton: Folic acid mg 150.00, $178.00 \mathrm{mg}$ Cobalt, Copper 2675.00 mg, Hill $120.00 \mathrm{~g}$, Colistin 2,000.00 mg, $11.00 \mathrm{~g}$ Iron, Iodine $535.00 \mathrm{mg}$ Manganese 31, $00 \mathrm{~g}, 350.00 \mathrm{~g}$ mineral matter, Niacin 7,200.00 mg, Nicarbazin $24.00 \mathrm{~g}$, Calcium pantothenate 2,400.00 mg, $60.00 \mathrm{mg}$ Selenium, Vitamin A 1,920,000.00 IU, Vitamin B1 $300.00 \mathrm{mg}$, Vitamin B12 3,600.00 mg, Vitamin B2 1,200.00 mg, Vitamin B6 450.00 mg, Vitamin D3 360,000.00 IU, Vitamin E 3600.00 IU, Vitamin H 18.00 mg, Vitamin K 480.00 mg, Zinc $22.00 \mathrm{~g}$.

${ }^{2}$ Calculated as Mongin (1981): Electrolyte balance $=(\mathrm{mg} / \mathrm{kg}$ diet of $\mathrm{Na}+/ 22.990)+(\mathrm{mg} / \mathrm{kg} \operatorname{diet}$ of the $\mathrm{K}+/ 39.102)-(\mathrm{mg} / \mathrm{kg}$ of feed Cl-/35.453). 
Two broilers from each experiment with a body weight near the middle of the plot $( \pm 5 \%)$ were subjected to fasting for 12 hours and killed by cervical dislocation at 21 days of age. Afterwards, they were submitted to bleeding, blanching, plucking and gutting procedures. Edible guts (gizzard, heart and liver) and small intestine were collected during evisceration, then cleaned and dried on paper towels and weighed separately on a precision scale. All the fat was removed from the gizzard, its contents and the coilin membrane. In addition to the weight, the intestine length was measured from the beginning of the duodenum to the ileocecal junction. The relative weight of the plucked and eviscerated carcass was calculated based on the weight ratio during fasting. The relative weights of edible guts and small intestine were obtained in relation to the plucked and eviscerated carcass.

The data of variables were submitted to normality tests (Cramér-von Mises) and homoscedasticity (Levene). Variables were subjected to analysis of variance using the statistical model once these assumptions were met:

$$
\mathrm{Y}_{\mathrm{ij}}=\mu+\mathrm{NS}_{\mathrm{i}}+\mathrm{e}_{\mathrm{ij} ;} \text { as } \mathrm{i}=1,2,3,4 ; \mathrm{j}=1,2,3,4,5 \text {, }
$$

where $Y \mathrm{ij}=$ observed value for the variable of interest in broilers of the $\mathrm{j}$-th repetition receiving the i-th level of replacement of soybean meal with babassu pie; $\mu=$ effect of general average; NSi $=$ effect of the i-th level of replacement of soybean meal with babassu pie; eij = experimental error.

The variables, whose effects of replacing soybean meal with babassu pie were detected by analysis of variance $(\mathrm{P} \leq 0.05)$, were subjected to regression analysis using polynomial models of the first or second order considering the level of replacement of soybean meal with babassu pie as an independent variable. To check the equations adjustment the significance of the " $F$ " test for the models, the significance of the " $t$ " test for the parameters $(\beta 0$, $\beta 1$ and $\beta 2$ ) of the models and the coefficients of determination $(\mathrm{R} 2=\mathrm{SQ}$ model $/ \mathrm{SQ}$ treatment $)$ were considered. The treatment averages were additionally compared using the Student Newman Keuls test (SNK) considering a significance level equal to or less than $5 \%$. Statistical analyses were performed with SAS Software 9.0 (2002).

The feeding costs were determined considering that the treatments were applied in production systems that required the same inputs, but different meals. Only the calculation of expenses in poultry feed was used to quantify the cost differential between one treatment and another (PEREIRA et al., 2003).

To compare the economic efficiency of the experimental diets the feed cost per $\mathrm{kg}$ of chicken produced was determined as follows:

$$
\mathrm{FC}_{\mathrm{i}}=\left(\mathrm{AMC}_{\mathrm{i}} \times \mathrm{MC}_{\mathrm{i}}\right) / \mathrm{WP}_{\mathrm{i}} \text {; as i }=1,2,3,4 .
$$

In this $\mathrm{FC}_{\mathrm{i}}=$ feed cost per $\mathrm{kg}$ of chicken produced with the use of the $i$-th level of replacement of soybean meal with babassu pie (US\$/kg), $\mathrm{AMC}_{\mathrm{i}}$ $=$ amount of meal consumed in the ith level replacement of soybean meal with babassu pie $(\mathrm{kg}), \mathrm{MC}_{\mathrm{i}}=$ cost of meal containing the ith level of replacement of soybean meal with babassu pie (US\$ $/ \mathrm{kg}$ ), and $\mathrm{WG}_{\mathrm{i}}=$ the weight gain of broilers receiving the ith level of replacement of soybean meal with babassu pie $(\mathrm{kg})$.

The gross margin in relation to the cost of food per $\mathrm{kg}$ of chicken for every level of substitution of soybean meal for babassu pie in the diets was calculated by the formula: = GMi PVF - Cfi, where $\mathrm{GMi}=$ gross margin related to the cost of feed per $\mathrm{kg}$ of chicken obtained with the use of the i-th level of replacement of soybean meal with babassu pie $(\mathrm{R} \$) ; \mathrm{PLC}=$ selling price of live chicken $(\mathrm{R} \$ / \mathrm{kg})$; and $\mathrm{CPCi}=$ cost per $\mathrm{kg}$ of chicken produced with the use of the $\mathrm{i}$-th level of replacement of soybean meal with babassu pie (US\$/kg). 


\section{Results and Discussion}

The average maximum and minimum temperatures within the premises during the experimental period were $25.4 \pm 0.82,29.3 \pm$ 1.63 and $21.6 \pm 0.69{ }^{\circ} \mathrm{C}$, respectively, and the relative humidity of the air was $58 \%$. These data demonstrated that the broilers remained within the thermal neutral zone throughout the complete experimental period while the temperature and the relative humidity remained within the environmental recommendations considered comfortable for that category (MEDEIROS et al., 2005; OLIVEIRA et al., 2006).

It was observed that the substitution of soybean meal with babassu pie influenced $(\mathrm{P}<0.05)$ the weight gain (WG), feed conversion (FC), water intake (H2OI) and weight of the broilers of 21 days of age (P21d), with no effect $(\mathrm{P}>0.05)$ on feed intake (FI) (Table 3).

Table 3. Average values of feed intake (FI), weight gain (WG), feed conversion (FC), water intake (IH2O) and weight at 21 (W 21d) days of broilers, according to the replacement level of soybean meal with babassu pie

\begin{tabular}{lcccccc}
\hline \multirow{2}{*}{ Variables } & \multicolumn{2}{c}{ Levels of replacement of soybean meal by babassu pie (\%) } & \multirow{2}{*}{$\mathrm{CV}^{1}$} & \multirow{2}{*}{$\mathrm{P}>\mathrm{F}^{2}$} \\
\cline { 2 - 5 } & 0 & 10 & 20 & 30 & & \\
\hline $\mathrm{FI}(\mathrm{g})$ & $1089.72 \pm 4.7$ & $1060.72 \pm 5.3$ & $1078.12 \pm 9.1$ & $1088.05 \pm 17.9$ & 1.82 & 0.1263 \\
$\mathrm{WG}(\mathrm{g})^{3}$ & $727.90^{\mathrm{a}} \pm 2.9$ & $684.40^{\mathrm{b}} \pm 4.4$ & $697.10^{\mathrm{b}} \pm 5.8$ & $687.38^{\mathrm{b}} \pm 5.2$ & 1.99 & 0.0007 \\
$\mathrm{FC}(\mathrm{g} / \mathrm{g})^{4}$ & $1.49^{\mathrm{a}} \pm 0.01$ & $1.55^{\mathrm{b}} \pm 0.01$ & $1.55^{\mathrm{b}} \pm 0.01$ & $1.58^{\mathrm{b}} \pm 0.01$ & 1.55 & 0.0007 \\
$\mathrm{IH}_{2} \mathrm{O}(\mathrm{mL})^{4}$ & $2129.00^{\mathrm{a}} \pm 18.4$ & $1961.30^{\mathrm{b}} \pm 10.9$ & $2004.28^{\mathrm{b}} \pm 31.3$ & $1914.84^{\mathrm{b}} \pm 37.5$ & 3.64 & 0.0018 \\
$\mathrm{~W} 21 \mathrm{~d}(\mathrm{~g})^{3}$ & $775.90^{\mathrm{a}} \pm 2.9$ & $732.40^{\mathrm{b}} \pm 4.5$ & $745.12^{\mathrm{b}} \pm 5.8$ & $735.38^{\mathrm{b}} \pm 5.2$ & 1.86 & 0.0007 \\
\hline
\end{tabular}

${ }^{1}$ Coefficient of variation (\%).

${ }^{2}$ Testing significance "F" analysis of variance.

${ }^{3}$ Quadratic effect.

${ }^{4}$ Linear effect.

The voluntary feed intake of broilers is related to the energetic levels contained in their meals. Therefore high energy levels can promote a reduction in consumption (MENDES et al., 2004). The absence of any effect on broilers may be related to the fact that experimental diets were formulated to be isocaloric $(2950 \mathrm{kcal} / \mathrm{kg})$, meeting the requirements $(\mathrm{kcal} / \mathrm{kg})$ of broilers regardless of the replacement level of soybean meal with babassu pie.

The WG of broilers decreased with the replacement of soybean meal by babassu pie according to the equation: $\mathrm{WG}(\mathrm{g})=724.02$ to 3.665 $\mathrm{NS}+0.0868 \mathrm{NS}^{2}\left(\mathrm{P}=0.0046 ; \mathrm{r}^{2}=0.74\right)$, where NS $=$ substitution level of soybean pie by babassu pie $(\%)$.

The absence of any effect on the MC associated with a reduction in WG resulted in the worsening of
FC according to the equation: $\mathrm{FC}(\mathrm{g} / \mathrm{g})=0.00254+$ $1.506 \mathrm{NS}\left(\mathrm{P}=0.0002 ; \mathrm{r}^{2}=0.88\right)$.

The IH2O was reduced with the substitution of soybean meal by babassu pie according to the equation: $\mathrm{CH}_{2} \mathrm{O}(\mathrm{mL})=2092$ to $5.995 \mathrm{NS}\left(\mathrm{r}^{2}=\right.$ 0.71; $\mathrm{P}<0.0018)$. According to Borges et al. (2003) and Oliveira et al. (2010), the electrolyte balance of the feed is directly related to water intake, so larger relations $\mathrm{Na}^{+}+\mathrm{K}^{+}-\mathrm{Cl}^{-}$cause increased intake. Whereas the soybean meal used in the formulation of the experimental diets contained $1.83 \%$ potassium while the babassu pie contained $0.48 \%$ (Table 1 ), increasing levels of substitution of soybean meal with babassu pie promoted a reduction in graded concentrations of potassium and thereby reduced the electrolyte balance of the feed $212.3177 .0 \mathrm{mEq} /$ $\mathrm{kg}$ (Table 2), which may explain the reduction of IH2O by broilers. 
Just like the WG, W21d was reduced with the substitution of soybean meal with babassu pie according to the equation: W21d $(\mathrm{g})=772,014-$ $3,664 \mathrm{NS}+0,0868 \mathrm{NS}^{2}\left(\mathrm{P}=0.0046 ; \mathrm{r}^{2}=0,74\right)$.

In general, there was worsening of the performance characteristics of chickens aged one to 21 days, depending on the substitution levels of soybean meal by babassu pie. Divergent results were found by Santos Neta et al. (2011) who found no effect on the performance of chickens aged one to 21 days fed with increasing levels $(0,4,8$ and $12 \%$ ) for including babassu pie in their diets. However, it should be emphasized that in the study conducted by the authors the experimental diets had fixed levels of inclusion of babassu pie and variable levels of corn and soybean meal, in contrast to what is proposed in this study, which was only the replacement of soybean meal by babassu pie so that the amount of corn in the experimental diets remained constant for all treatments $(0,10,20$ and $30 \%$ ).

Increasing the fiber content of the feed can impair nutrient utilization since the fiber acts as a physical barrier preventing endogenous enzymes from accessing the internal content of plant cells by interfering with the digestion and absorption of nutrients (IJI et al., 2001; JANSSEM; CARRE, 1989). According to several authors (MAISONNIER et al., 2001; VAN SOEST et al., 1991), the majority of physiological and antinutritional effects of fiber for monogastric animals are associated with fractions not considered by the crude fiber as nonstarch polysaccharides and hemicelluloses. Therefore, Jeraci and Van Soest (1990) considered the NDF an important component for characterizing the fiber of animal feed, including broilers, because this component includes cellulose, lignin and hemicellulose, while the crude fiber involves only cellulose and insoluble lignin.

Braz et al. (2011) evaluated the effects of fiber in laying-hen meals on growth and behavior and showed that the increase in NDF levels influenced their development, resulting in lighter broilers in lay. Based on this, the replacement of soybean meal with babassu pie $(0,10,20$ and $30 \%)$ promoted an increase in the NDF concentration $(15.552,16.851$, 18.149 and $19.447 \%$, Table 2 ) of the diets used in this study, which may explain the reduction in bird performance.

The replacement levels of soybean meal with babassu pie did not affect $(\mathrm{P}>0.05)$ the relative weights of the heart and liver, nor the relative weight or length of the small intestine (Table 4). Meanwhile, the effect $(\mathrm{P}<0.05)$ over the relative gizzard weight increased linearly according to the equation: $\mathrm{GW}=0.0121+2.701 \mathrm{NS}\left(\mathrm{P}=0.0044 ; \mathrm{r}^{2}\right.$ $=0.58)$.

Table 4. Relative weights for edible guts (heart, gizzard and liver) and small intestine and length of the small intestine (m) of broilers at 21 days of age.

\begin{tabular}{lcccccc}
\hline \multirow{2}{*}{ Variables } & \multicolumn{2}{c}{ Levels of replacement of soybean meal by babassu pie (\%) } & \multirow{2}{*}{ CV $^{1}$} & \multirow{2}{*}{$\mathrm{P}>\mathrm{F}^{2}$} \\
\cline { 2 - 5 } & 0 & 10 & 20 & 30 & & \\
\hline Heart (\%) & $0.76 \pm 0.04$ & $0.83 \pm 0.03$ & $0.78 \pm 0.02$ & $0.76 \pm 0.02$ & 11.12 & 0.5882 \\
Gizzard (\%) & $2.59^{\mathrm{b}} \pm 0.04$ & $3.03^{\mathrm{a}} \pm 0.06$ & $2.86^{\mathrm{ab}} \pm 0.02$ & $3.05^{\mathrm{a}} \pm 0.05$ & 4.87 & 0.0003 \\
Liver (\%) & $3.19 \pm 0.11$ & $3.55 \pm 0.10$ & $3.43 \pm 0.07$ & $3.37 \pm 0.11$ & 8.87 & 0.3168 \\
Small intestine (\%) & $4.22 \pm 0.10$ & $4.59 \pm 0.10$ & $4.54 \pm 0.11$ & $4.52 \pm 0.07$ & 5.95 & 0.1626 \\
Small intestine (m) & $1.33 \pm 0.03$ & $1.27 \pm 0.01$ & $1.28 \pm 0.03$ & $1.26 \pm 0.02$ & 5.11 & 0.4355 \\
\hline
\end{tabular}

${ }^{1}$ Coefficient of variation ( $\left.\%\right)$.

${ }^{2}$ Testing Significance "F" analysis of variance.

${ }^{3}$ Linear effect. 
Several studies have evaluated the effects of including fiber in the diet on the development and physiology of the digestive tract of broilers and found that increased levels of fiber increased the relative weight of various digestive organs, especially the gizzard (GONZÁLEZ-ALVARADO et al., 2007, 2008; JIMÉNEZ-MORENO et al., 2009, 2010; SACRANIE et al., 2012).

According to González-Alvarado et al. (2007, 2008), high levels of fiber in the diet promote mechanical stimulation of the gizzard causing a muscular adaptation to meet the higher demand for milling, which results in an increase in size of this organ and therefore its weight. Thus, the increase in fiber levels of the experimental diets due to the increase of soybean meal replacement levels by babassu pie may have been responsible for the increased relative weight of the gizzards of the broilers.

Based on the cost analysis of feeding, a higher gross margin was obtained with the chickens fed with $0 \%$ of babassu pie due to the lower cost of the food (Table 5). Increased levels of substitution of soybean meal with babassu pie promoted an increase in food cost due to the increase of soybean oil and synthetic amino acids, to maintain the energy balance and amino acidic diets. So it can be seen that in the conditions in which this work was carried out, it was not economically feasible to replace soybean meal with babassu pie to feed broilers between one and 21 days old because the cost of food is influenced by the price variations of the inputs and different regions of the country.

Table 5. Weight gain $(\mathrm{g})$, feed cost $(\mathrm{R} \$ / \mathrm{kg})$, feed cost per $\mathrm{kg}$ of weight gain $(\mathrm{R} \$ / \mathrm{kg})$ and gross margin $(\mathrm{R} \$ / \mathrm{kg})$ of 1 broilers 21 days.

\begin{tabular}{lcccc}
\hline \multirow{2}{*}{\multicolumn{1}{c}{ Variables }} & \multicolumn{4}{c}{ Levels replacement of soyabean meal by babassu pie (\%) } \\
\cline { 2 - 5 } & 0 & 10 & 20 & 30 \\
\hline Weight gain $(\mathrm{g})$ & 727.90 & 684.40 & 697.10 & 687.38 \\
Feed cost ${ }^{1}(\mathrm{R} \$ \mathrm{~kg})$ & 0.999 & 1.001 & 1.003 & 1.005 \\
Feed cost per kg of WG $(\mathrm{R} \$ / \mathrm{kg})$ & 1.481 & 1.566 & 1.570 & 1.573 \\
Gross margin $^{2}(\mathrm{R} \$ / \mathrm{kg})$ & 1.319 & 1.234 & 1.230 & 1.227 \\
\hline
\end{tabular}

${ }^{1}$ Considering the following prices: Corn $=\mathrm{R} \$ 0.59 / \mathrm{kg}$; Soybean meal $=\mathrm{R} \$ 1.30 / \mathrm{kg}$; babassu pie $=\mathrm{R} \$ 0.70 / \mathrm{kg}$; Dicalcium phosphate $=\mathrm{R} \$ 2.77 / \mathrm{kg} ;$ Soybean oil $=\mathrm{R} \$ 2.49 / \mathrm{kg} ;$ Limestone $=\mathrm{R} \$ 0.43 / \mathrm{kg} ;$ Ps $=0.80 / \mathrm{kg} ;$ DL-methionine $=\mathrm{R} \$ 11.87 / \mathrm{kg} ; \mathrm{L}-\mathrm{lysine} \mathrm{HCl}=$ $\mathrm{R} \$ 6.67 / \mathrm{kg} ; \mathrm{L}-$ threonine $=\mathrm{R} \$ 6.76 / \mathrm{kg} ;$ Mineral and vitamin supplement $=\mathrm{R} \$ 9.00 / \mathrm{kg}$.

${ }^{2}$ Considering the price of live chicken paid on $17 / 02 / 2012$ of $\mathrm{R} \$ 2.80 / \mathrm{kg}$ from the company ASA North.

Given the conditions under which the experiment was conducted, the results showed that the substitution of soybean meal with babassu pie detracted from the performance of broilers between 1 and 21 days of age, which makes it technically and economically unfeasible, even if the energy levels and the amino acidic of the diet are balanced, to meet the requirements of the broilers.

\section{Conclusion}

The replacement of soybean meal by babassu pie detracted from broiler performance in the one to 21 days of age phase, which makes it technically and economically unfeasible under the conditions in which the study was conducted.

\section{Acknowledgment}

The National Council for Scientific and Technological Development (CNPq) for the granting of the scholarship. 


\section{References}

BASTOS, S. C.; FUENTES, M. F. F.; FREITAS, E. R.; ESPÍNDOLA, G. B.; BRAGA, C. V. P. Efeito da inclusão do farelo de coco em rações para frangos de corte. Revista Ciência Agronômica, Fortaleza, v. 38, n. 3, p. 297-303, 2007.

BORGES, S. A.; FISCHER DA SILVA, A. V.; ARIKI, J.; HOOGE, D. M.; CUMMINGS, K. R. Dietary electrolyte balance for broiler chickens exposed to thermoneutral or heat-stress environments. Poultry Science, Champaign, v. 82, n. 3, p. 428-435, 2003.

BRAZ, N. M. de; FREITAS, E. R.; BEZERRA, R. M.; CRUZ, C. E. B.; FARIA, N. N. P.; SILVA, N. M. da; SÁ, N. L.; XAVIER, R. P. S. Fibra na ração de crescimento e seus efeitos no desempenho de poedeiras nas fases de crescimento e postura. Revista Brasileira de Zootecnia, Viçosa, MG, v. 40, n. 12, p. 2744-2753, 2011.

BRUNELLI, S. R.; PINHEIRO, J. W.; SILVA, C. A. da; FONSECA, N. A. N.; OLIVEIRA, D. D. de; CUNHA, G. E.; SOUZA, L. F. A. de. Inclusão de farelo de gérmen de milho desengordurado na alimentação de frangos de corte. Revista Brasileira Zootecnia, Viçosa, MG, v. 35, n. 4, p. 1349-1358, 2006.

CARNEIRO,A.P. M.; PASCOAL, L.A. F.; WATANABE, P. H.; SANTOS, I. B.; LOPES, J. M.; ARRUDA, J. C. B. de. Farelo de babaçu em rações para frangos de corte na fase final: desempenho, rendimento de carcaça e avaliação econômica. Ciência Animal Brasileira, Goiânia, v. 10, n. 1, p. 40-47, 2009.

GONZÁLEZ-ALVARADO, J. M.; JIMÉNEZMORENO, E.; LAZÁRO, R.; MATEO, G. G. Effect of type of cereal, heat processing of the cereal, and inclusion of fiber in the diet on productive performance and digestive traits of broilers. Poultry Science, Champaign, v. 86, n. 8, p. 1705-1715, 2007.

GONZÁLEZ-ALVARADO, J. M.; JIMÉNEZMORENO, E.; VALENCIA, D. G.; LÁZARO, R.; MATEOS, G. G. Effects of fiber source and heat processing of the cereal on the development and $\mathrm{pH}$ of the gastrointestinal tract of broilers fed diets based on corn or rice. Poultry Science, Champaign, v. 87, n. 9, p. 1779-1795, 2008.

HENZ, J. R.; NUNES, R. V.; POZZA, P. C.; FURLAN, A. C.; SCHERER, C.; EYNG, C.; SILVA, W. T. M. Valores energéticos de diferentes cultivares de milho para aves. Semina Ciências Agrárias, Londrina, v. 34, n. 5, p. 2403-2414, 2013.

IJI, P. A.; SAKI, A. A.; TIVEY, D. R. Intestinal development and body growth of broiler chicks on diets supplemented with non-starch polysaccharides. Animal
Feed Science and Technology, Amsterdam, v. 89, n. 3, p. 175-188, 2001.

JANSSEM, W. M. M. A.; CARRÉ, B. Influence of fiber on digestibility of poultry feeds. In: COLE, D. J. A.; HARESIGN, W. (Ed.). Recent developments in poultry nutrition. London: Butterworths, 1989. p. 78-93.

JERACI, J. L.; VAN SOEST, P. J. Improved methods for analysis and biological characterization of fiber. Advances in Experimental Medicine and Biology, New York, v. 270, n. 2, p. 245-263, 1990.

JIMÉNEZ-MORENO, E.; GONZÁLES-ALVARADO, J. M.; GONZÁLES-SÁNCHEZ, D.; LÁZARO, R.; MATEOS, G. G. Effects of type and particle size of dietary fiber on growth performance and digestive traits of broilers from 1 to 21 days of age. Poultry Science, Champaign, v. 89, n. 10, p. 2197-2212, 2010.

Effect of dietary fiber and fat on performance and digestive traits of broilers from one to twenty-one days of age. Poultry Science, Champaign, v. 8, n. 12, p. 2562-2574, 2009.

MAISONNIER, S.; GOMEZ, J.; CARRÉ, B. Nutrient digestibility and intestinal viscosities in broiler chickens fed on wheat diets, as compared to maize diets with added guar gum. British Poultry Science, London, v. 42, n. 1, p. 102-110, 2001.

MEDEIROS, C. M.; BAÊTA, F. C.; OLIVEIRA, R. F. M.; TINÔCO, I. F. F.; ALBINO, L. F. T.; CECON, P. R. Efeitos da temperatura, umidade relativa e velocidade do ar em frangos de corte. Engenharia na Agricultura, Viçosa, MG, v. 13, n. 4, p. 277-286, 2005.

MENDES, A. A.; MOREIRA, J.; OLIVEIRA, E. G. de; GARCIA, E. A.; ALMEIDA, M. I. M. de; GARCIA, R. G. Efeitos da energia da dieta sobre desempenho, rendimento de carcaça e gordura abdominal de frangos de corte. Revista Brasileira de Zootecnia, Viçosa, MG, v. 33, n. 6, p. 2300-2307, 2004.

MONGIN, P. Recent advances in dietary cation-anion balance: applications in poultry. Proceedings Nutrition Society, Cambridge, v. 40, n. 3, p. 285-294, 1981.

NASCIMENTO, G. A. J. do; COSTA, F. G. P.; AMARANTE JÚNIOR, V. S.; BARROS, L. R. Efeitos da substituição do milho pela raspa de mandioca na alimentação de frangos de corte, durante as fases de engorda e final. Ciência Agrotecnologia, Lavras, v. 29, n. 1, p. 200-207, 2005.

OLIVEIRA, M. C.; ARANTES, U. M.; STRINGHINI, J. H. Efeito do balanço eletrolítico da ração sobre parâmetros ósseos e da cama de frango. Revista Biotemas, Florianópolis, v. 23 n. 1, p. 203-209, 2010. 
OLIVEIRA, R. F. M.; DONZELE, J. L.; ABREU, M. L. T.; FERREIRA, R. A.; VAZ, R. G. M. V.; CELLA, P. $S$. Efeitos da temperatura e da umidade relativa sobre o desempenho e o rendimento de cortes nobres de frangos de corte de 1 a 49 dias de idade. Revista Brasileira de Zootecnia, Viçosa, MG, v. 35, n. 3, p. 797-803, 2006.

PEREIRA, J. C.; SILVA, P. R. C.; CECON, P. R.; RESENDE FILHO, M. A.; OLIVEIRA, R. L. Cama de frango e suplemento à base de microbiota ruminal em dietas de novilhas leiteiras: desempenho produtivo e avaliação econômica. Revista Brasileira de Zootecnia, Viçosa, MG, v. 32, n. 3, p. 653-662, 2003.

RAMOS, L. S. N.; LOPES, J. B.; FIGUEIRÊDO, A. V.; FREITAS, A. C.; FARIAS, L. A.; SANTOS, L. S.; SILVA, H. O. Polpa de caju em rações para frangos de corte na fase final: desempenho e características de carcaça. Revista Brasileira de Zootecnia, Viçosa, MG, v. 35, n. 3, p. 804-810, 2006.

ROSTAGNO, H. S.; ALBINO, L. F. T.; DONZELE, J. L.; GOMES, P. C.; OLIVEIRA, R. F. de; LOPES, D. C.; FERREIRA, A. S.; BARRETO, S. L. de T. Tabelas brasileiras para aves e suínos composição de alimentos $e$ exigências nutricionais. Viçosa: UFV, Imprensa Universitária, 2011. 252 p.

SACRANIE, A.; SVIHUS, B.; DENSTADLI, V.; MOEN, B.; IJI, P. A.; CHOCT, M. The effect of insoluble fiber and intermittent feeding on gizzard development, gut motility, and performance of broiler chickens. Poultry Science, Champaign, v. 91, n. 3, p. 693-700, 2012.
SANTOS NETA, E. R. Avaliação de subprodutos do babaçu (Palmae orbignya martiana) na alimentação de frangos de corte. 2010. Dissertação (Mestrado em Ciência Animal Tropical) - Universidade Federal do Tocantins, Araguaína.

SANTOS NETA, E. R. dos; VAZ, R. G. M. V.; RODRIGUES, K. F.; SOUSA, J. P. L.; PARENTE, I. P.; ALBINO, L. F. T.; SIQUEIRA, J. C. de; ROSA, F. C. Níveis de inclusão da torta de babaçu em rações de frangos de corte na fase inicial. Revista Brasileira Saúde Produção Animal, Salvador, v. 12, n. 1, p. 234-243, 2011.

SCHOULTEN, N. A.; TEIXEIRA, A. S.; RODRIGUES, P. B.; FREITAS, R. T. F. de; CONTE, A. J.; SILVA, H. O. Desempenho de frangos de corte alimentados com ração contendo farelo de arroz e enzimas. Ciência Agrotecnologia, Lavras, v. 27, n. 6, p. 1380-1387, 2003.

STATISTICAL ANALYSES SYSTEM - SAS. SAS/ INSIGHT User's guide. Versão 9. 0 - versão para Windows. Cary: SAS Institute, 2002. CD-ROM.

VAN SOEST, P. J.; ROBERTSON, J. B.; LEWIS, B. A. Methods for dietary fiber, neutral detergent fiber and nonstarch polysaccharides in relation to animal nutrition. Journal of Dairy Science, Cambridge, v. 74, n. 10, p. 3583-3597, 1991. 